\section{Dissektion der A. carotis communis nach Anlage eines zentralen Venenkatheters}

\author{
Einführung
}

Eine spontane Dissektion der A. carotis kann auf dem Boden von Gefäßerkrankungen wie einer fibromuskulären Dysplasie oder einer zystischen Medianekrose auftreten. Die Dissektion betrifft vornehmlich die A. carotis interna und stellt eine wesentliche Ursache für einen Schlaganfall dar. (J.U. Harrer et al. Ultraschall in Med 2006; 27: 487-488). Bei der iatrogenen Carotisdissektion handelt es sich um eine bekannte Komplikation einer versehentlichen Punktion der A. carotis bei der Anlage eines V. jugularisKatheters. Die Inzidenz einer akzidentellen arteriellen Punktion wird mit ungefähr 3\% angegeben, aber nicht alle Vorkommnisse sind klinisch relevant (S. Ruesch et al. Crit Care Med 2002; 30: 454-460). Die Farbduplex-Untersuchung gilt als Methode der Wahl zur Feststellung einer Dissektion der A. carotis (C. Arning. Ultraschall in Med 2005; 26: 24-28).

\section{Fallbericht}

$\checkmark$

Bei einem 41jährigen Mann mit terminaler Niereninsuffizienz wurde ein permanenter Venenkatheter (PermcathTM) für die Hämodialyse angelegt, was zu einer Thrombose der rechten V. jugularis führte. Nach Entfernen dieses Katheters und anschließender Anlage eines neuen Katheters in der kontralateralen V. subclavia wurde die orale Antikoagulation mit Phenprocoumon (Marcumar ${ }^{\circledR}$ ) begonnen. Der Patient wurde zur LebendnierenTransplantation an unsere Klinik überwiesen. Die Kontrolluntersuchung vor Transplantation mittels Duplex-Sonographie bestätigte die Jugularvenenthrombose, wies aber zusätzlich eine asymptomatische Dissektion der A. carotis communis nach. Die Farbduplex-Untersuchung zeigte eine umschriebene Läsion der Arterie mit Umgebungshämatom (Abb. 1 und 2) sowie ein Stück Dissektionsmembran mit zwei perfundierten Lumina (Abb. 2). Die Dissektion verursachte eine arterielle Stenose (>50\%) mit eindrucksvollen Turbulenzen. Die hämodynamischen Veränderungen bestanden in einer Verdreifachung der Spitzenflussgeschwindigkeit innerhalb der Stenose (Abb. 3) sowie einer frühsystolischen Dezeleration sowohl in der distalen A. carotis communis als auch in der A. carotis interna und externa, wahrscheinlich verursacht durch die retrograde Druckwelle von der kontralateralen Seite. Diese Art der Druckwelle (Abb. 3d) sieht man regelmäßig in der A. vertebralis beim Vorliegen eines SubclavianSteel-Syndroms mit Einflussstenose. In der A. carotis communis ist dieses Phänomen hingegen nicht beschrieben. Die Nierentransplantation wurde verschoben und die Antikoagulation weitergeführt. Nach zwei Monaten war die Dissektionsmembran verschwunden, die Spektralwellenformen in der A. carotis communis, interna und externa waren normal, und man fand nur noch eine kleine umschriebene Verdickung mit einem minimalen echoarmen perivaskulären Saum (Abb. 4).

\section{Common Carotid Dissection after Central Venous Catheterisation}

\author{
Introduction \\ $\nabla$
}

Spontaneous carotid artery dissection can occur due to vascular diseases such as fibromuscular dysplasia and cystic media necrosis. The dissection mostly affects the internal carotid artery and is an important cause of stroke (Harrer JU et al. Ultraschall in Med 2006; 27: 487-488). Iatrogenic carotid artery dissection is a known complication of accidental arterial puncture during internal jugular vein catheterization. The incidence of accidental arterial puncture is reported to be around 3\%, but not all occurrences are clinically relevant (Ruesch S et al. Crit Care Med 2002; 30: 454-460). Color-coded duplex ultrasound is considered to be the first-line method for diagnosing carotid artery dissection (Arning C. Ultraschall in Med 2005; 26: 24-28).

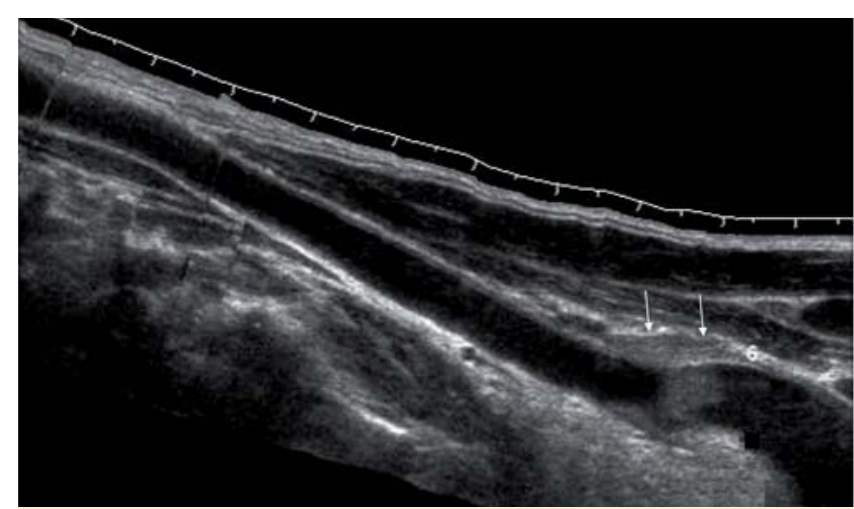

Abb. 1 Längsschnitt („panorama“-view) der Arteria carotis communis rechts proximal: lokalisierte, relativ scharf abgegrenzte echogene Struktur ausserhalb der Gefässwand (Hämatom, Pfeile) und intraluminaler Thrombus.

Fig. 1 Longitudinal ("panorama") view of the common carotid artery (proximal part on the right): localized, relatively sharply delineated echogenic structure outside the vessel wall (hematoma, arrows) and intraluminal thrombus.

\section{Case report}

$\checkmark$

A 41-year-old man with end stage renal disease underwent implantation of a permanent tunneled venous catheter (Permcath ${ }^{\mathrm{TM}}$ ) for hemodialysis resulting in thrombosis of the right jugular vein. After removal of this catheter and subsequent implantation of a new one on the contralateral subclavian vein, oral anticoagulation with phenprocoumon (Marcoumar ${ }^{\circledR}$ ) was started. The patient was referred to our hospital for living donor kidney transplantation. Pretransplant follow-up duplex ultrasound confirmed the jugular vein thrombosis but also revealed an asymptomatic common carotid artery dissection. Color-coded duplex showed a confined arterial lesion with a surrounding hematoma (Fig. 1 and 2) and a limited dissection membrane with two perfused lumina (Fig. 2). The dissection resulted in arterial stenosis (> 50\%) with impressive flow disturbances. The hemodynamic changes included an intrastenotic threefold increase in peak flow velocity (Fig. 3) and an early systolic deceleration in the distal 


\section{Diskussion}

$\nabla$

Jugularvenenthrombose und versehentliche arterielle Punktion stellen bekannte Komplikationen einer Katheterisierung der V. jugularis dar. Im Gegensatz zu einer Beteiligung der supraaortalen Äste der Aorta bei Typ-I-Aortendissektion (A. Lovrencic-Huzjan et al. Ultraschall in Med 2006; 27: 280-283) ist die Dissektion der A. carotis communis als Folge einer Katheterisierung der V. jugularis bisher nur in Fallberichten beschrieben, meist mit ungünstigem Verlauf (M. Reuber et al. Acta Neurol Scand 2002; 105 : 235-239). Trotz eindrucksvoller hämodynamischer Veränderungen blieb unser Patient asymptomatisch, und die Dissektion der common carotid artery as well as in the internal and external carotid artery, presumably due to the retrograde pressure wave from the contralateral side. This type of waveform (Fig. $3 \mathrm{~d}$ ) is routinely seen in the vertebral artery in the early phase of a subclavian steal syndrome with inflow stenosis. However, it has not been described in the common carotid artery. Kidney transplantation was postponed and oral anticoagulation was continued. Two months later the dissection membrane had disappeared, spectral waveforms in the common, internal, and external carotid artery were normal and only a slight focal enlargement with a minimal hypoechoic perivascular fringe was present (Fig. 4).
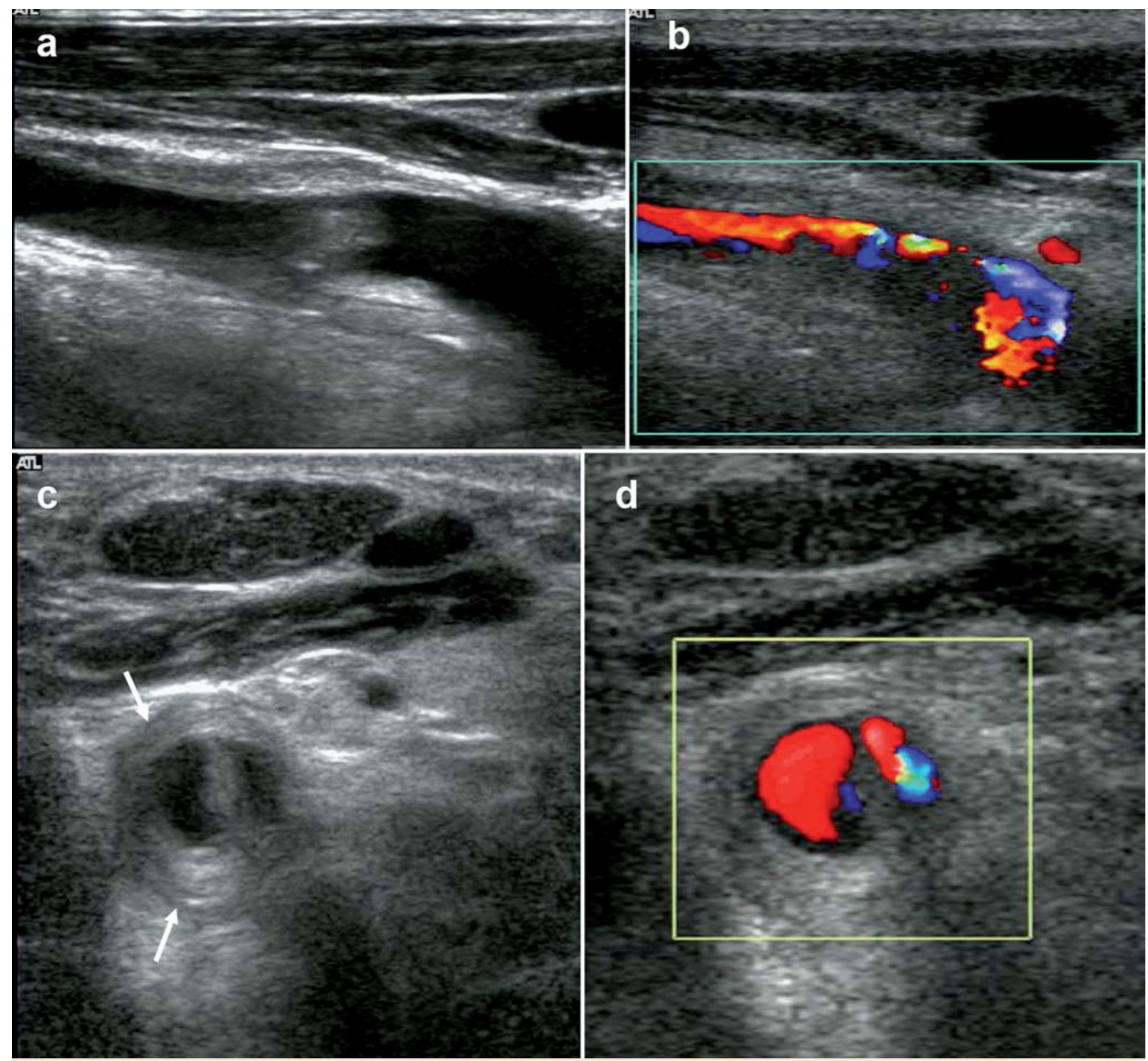

Abb. 2 a B-Mode Ultraschall - Längsschnitt: diffuse perivaskuläre echoarme Läsion und intraluminaler Thrombus im proximalen Anteil der Arteria carotis communis. b Farbkodierte Duplexsonographie - Längsschnitt: Einengung der Arterie und erhöhte Flussgeschwindigkeiten (gelb, grün) aufgrund der hämodynamisch wirksamen Stenose. c B-Mode Ultraschall - Querschnitt: Dissektionsmembran der Arteria carotis communis mit zirkulärem perivaskulärem Hämatom (Pfeile). d Farbkodierte Duplexsonographie - Querschnitt: Flussnachweis in beiden Gefässlumina.

Fig. 2 a. B-mode ultrasound - longitudinal section: diffuse perivascular hypoechogenic lesion and intraluminal thrombus in the proximal common carotid artery; b. Color-coded duplex ultrasound - longitudinal section: narrowing of the artery and increased flow velocities (yellow, green) due to hemodynamically significant stenosis; c. B-mode ultrasound (cross section): intraluminal dissection membrane of the common carotid artery and circumferential perivascular hematoma (arrows). d. Color-coded duplex ultrasound - cross section: flow in both lumina. 

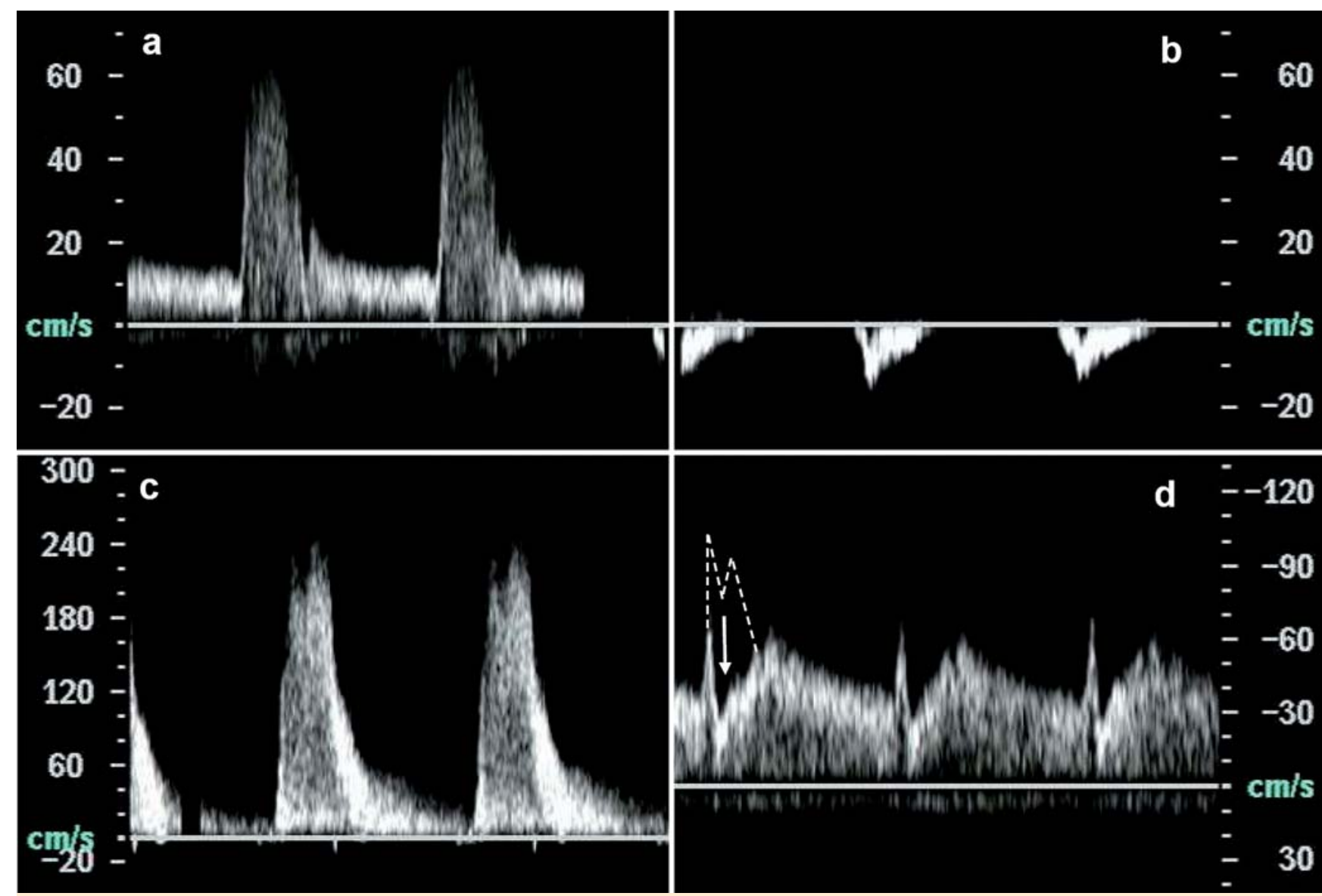

Abb. 3 Doppler-Spektralanalyse: a Arteria carotis communis: wahres Lumen mit "normaler" Kurvenform, Spektralverbreiterung. b Arteria carotis communis: falsches Lumen mit pathologischem retrogradem Fluss. c Arteria carotis communis: intrastenotisch erhöhte Spitzenflussgeschwindigkeit. $d$ Arteria carotis interna: „early systolic deceleration“ (erwartete Kurve als gestrichelte Linie).

Fig. 3 Doppler flow spectral analysis: a. common carotid artery true lumen, "normal" spectral wave form, spectral broadening; b. common carotid artery false lumen, pathological retrograde flow; c. common carotid artery intrastenotic increased peak systolic flow velocity; d. internal carotid artery with early systolic deceleration (expected curve form in dashed line).

A. carotis communis wurde nur zufällig entdeckt. Wir nehmen deshalb an, dass die Verletzung der A. carotis communis durch versehentliche Punktion häufiger auftritt als angegeben.

Man sollte beachten, dass die Duplex-Sonographie nicht nur wichtige hämodynamische und morphologische Informationen nach einer Verletzung der Arterie liefert, sondern auch ein wichtiges Instrument darstellt, um die Katheterisierung der V. jugularis zu erleichtern und Punktionskomplikationen zu vermeiden.

\section{Discussion}

$\nabla$

Jugular vein thrombosis and accidental arterial puncture are well known complications of jugular venous catheterization. In contrast to the involvement of the supraaortic branches in type A aortic dissection (Lovrencic-Huzjan A. et al. Ultraschall in Med 2006; 27: 280-283), common carotid artery dissection during jugular vein cannulation has been reported only in case reports, usually with unfavorable outcomes (Reuber M. et al. Acta Neurol Scand 2002; 105: 235-239). Despite impressive hemodynamic alterations, our patient remained asymptomatic and common carotid artery dissection was only detected by chance. Therefore, we speculate that common carotid injury due to accidental puncture during jugular vein catheter implantation might be more frequent than previously reported.

Notably, duplex ultrasound not only provides important hemodynamic and morphological information after an arterial injury but is also an important tool for facilitating jugular vein cannulation and preventing puncture related complications. 

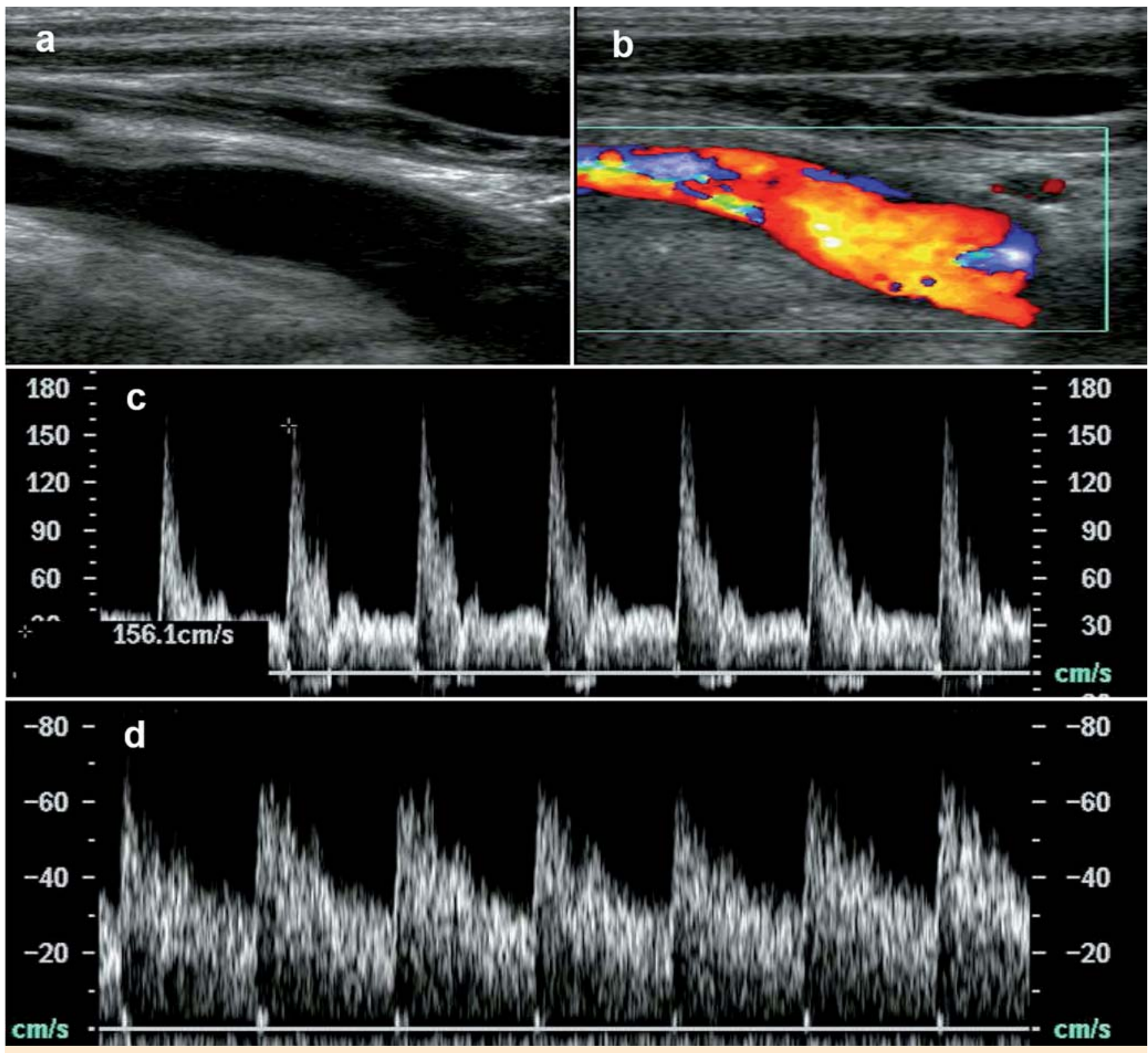

Abb. 4 a B-Mode Ultraschall und b farbkodierte Duplexsonographie nach acht Wochen Antikoagulation: Dissektionsmembran und intraluminaler Thrombus sind nicht mehr nachweisbar, das perivaskuläre Hämatom rückläufig. Doppler-Spektralanalyse nach acht Wochen Antikoagulation: c Arteria carotis communis und d Arteria carotis interna mit Normalisierung der Doppler-Flusskurve bei erhöhter Spitzenflussgeschwindigkeit (um $160 \mathrm{~cm} / \mathrm{s}$ ).

Fig. 4 a. B-mode ultrasound and b. color-coded duplex ultrasound after eight weeks of anticoagulation: disappearance of both the dissection membrane and the intraluminal thrombus with a reduction of the perivascular hematoma. Doppler spectral analysis after eight weeks of anticoagulation: c. common carotid artery and d. internal carotid artery with normalization of the Doppler flow pattern, peak systolic velocity increased (approximately $160 \mathrm{~cm} / \mathrm{s}$ ).

\section{Kernaussagen}

$\nabla$

- Die farbkodierte Duplexsonographie bietet morphologische und wichtige hämodynamische Informationen nach akzidenteller Punktion der Arteria carotis.

- Auch hämodynamisch auffällige Folgen nach iatrogener Gefässverletzung brauchen nicht unbedingt eine invasive Maßnahme zur Korrektur. Ein abwartendes Procedere in Einzelfällen ist gerechtfertigt.

- Die Duplexsonographie ist nicht nur in der Diagnostik von vaskulären Komplikationen die Bildgebung der Wahl, sondern kann möglicherweise auch die Komplikationsraten durch eine ultraschallgestützte Punktion reduzieren.

\section{Core Statements}

$\nabla$

- Color-coded duplex ultrasound provides morphological and important hemodynamic information after accidental puncture of the carotid artery.

- Although impressive hemodynamic alteration of the blood flow may be found after iatrogenic injury, an invasive intervention might not be required. A "wait and see" strategy may be justified in selected cases.

- Use of ultrasound is not only important for the diagnosis of accidental complications, but may also help to reduce puncturerelated problems (ultrasound-guided puncture).

M. Aschwanden, C. Thalhammer, S. Schaub, K. A. Jaeger, Basel 